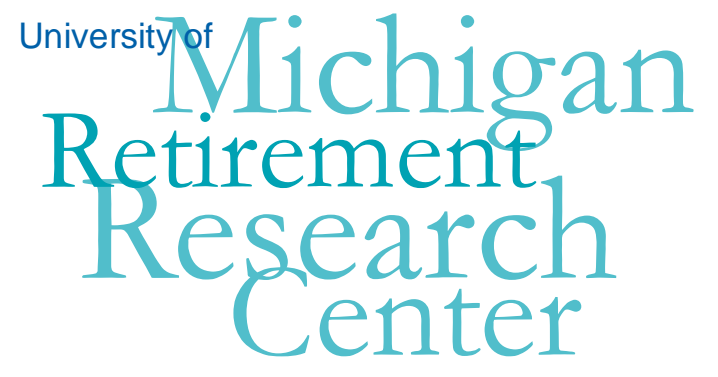

Working Paper

WP 2011-245

\title{
First-Round Impacts of the 2008 Chilean Pension System Reform
}

\author{
Jere R. Behrman, Maria Cecilia Calderon, Olivia S. Mitchell, \\ Javiera Vasquez, and David Bravo
}

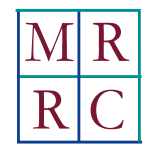

Project \#: UM11-05 



\title{
First-Round Impacts of the 2008 Chilean Pension System Reform
}

\author{
Jere R. Behrman \\ University of Pennsylvania \\ Author Maria Cecilia Calderon \\ Population Council
}

Olivia S. Mitchell

Wharton School, University of Pennsylvania

Javiera Vasquez

Universidad de Chile

David Bravo

Universidad de Chile

September 2011

\author{
Michigan Retirement Research Center \\ University of Michigan \\ P.O. Box 1248 \\ Ann Arbor, MI 48104 \\ http://www.mrrc.isr.umich.edu
}

(734) 615-0422

\section{Acknowledgements}

This work was supported by a grant from the Social Security Administration through the Michigan Retirement Research Center (Grant \# RRC08098401-03-00). The findings and conclusions expressed are solely those of the author and do not represent the views of the Social Security Administration, any agency of the Federal government, or the Michigan Retirement Research Center. 


\title{
First-Round Impacts of the 2008 Chilean Pension System Reform
}

\begin{abstract}
Chile's innovative privatized pension system has been lauded as possible model for Social Security system overhauls in other countries, yet it has also been critiqued for not including a strong safety net for the uncovered sector. In response, the Bachelet government in 2008 implemented reforms to rectify this shortcoming. Here we offer the first systematic effort to directly evaluate the reform's impacts, focusing on the new Basic Solidarity Pension for poor households with at least one person age 65+. Using the Social Protection Survey, we show that targeted poor households received about 2.4 percent more household annual income, with little evidence of crowding-out of private transfers. We also suggest that recipient household welfare probably increased due to slightly higher expenditures on basic consumption including healthcare, more leisure hours, and improved self-reported health. While measured short-run effects are small, follow-ups will be essential to gauge longer-run outcomes.
\end{abstract}

Author Acknowledgements

The authors acknowledge support provided by the Social Security Administration via a grant from the Michigan Retirement Research Center, the Pension Research Council and Boettner Center at the Wharton School of the University of Pennsylvania, and the National Institutes of Health/National Institute of Aging (NIA) grant AG023774-01(P.I. Petra Todd) on "Lifecycle health, work, aging, insurance and pensions in Chile." Opinions and errors are solely those of the authors and not of the institutions providing funding for this study or with which the authors are affiliated. (c) 2011 Behrman, Calderon, Mitchell, Vasquez and Bravo. 


\section{First-Round Impacts of the 2008 Chilean Pension System Reform}

Systematic research on the effects of alternative pension systems is useful to enhance the scientific basis for policy evaluation in the retirement arena. One of the most interesting, perhaps the most interesting, country in this regard has been Chile, which since 1981 has become a laboratory for observing the impacts of pension privatization. Specifically, for 30 years Chile has had mandatory individual retirement accounts managed by private-sector providers known as Pension Fund Managers (AFPs, Administradoras de Fondos de Pensiones). Formal-sector workers are required to save an annual 10 percent of their pay in their accounts, which offer some investment choice, and wherein they must preserve the funds until they reach retirement age.

Though the Chilean AFP system has numerous strengths, it has also been cited for paying low benefit levels and for having low rates of worker contributions (Berstein et al. 2006; Gill et al. 2005; Kritzer et al. 2011). Accordingly, in July 2008, the government of President Michelle Bachelet initiated several system-wide reforms intended to strengthen the national safety net for both the young and the old (Diaz et al. 2009). This paper evaluates how one key element of the 2008 Chilean reform, namely the Basic Solidarity Pension (PBS, Pension Básica Solidaria), influenced economic outcomes for targeted poor households with at least one member age 65 or older. We do so using the 2006 and 2009 Chilean Social Protection Surveys (EPS, Encuesta de Proteccion Social) and linked information from administrative data about the respondents to investigate resulting changes in knowledge of and receipt of these new transfers as well as changes in outcomes such as household work and health status and expenditures on alcohol and 
cigarette consumption, health insurance, and ownership of consumer durables. ${ }^{1}$ We address a wide range of outcomes because we posit that, as in standard economic household models, the reforms may have influenced behaviors in unanticipated or even undesirable ways from the policy perspective. Results indicate that targeted households with elderly individuals received about 2.4 percent more household annual income, with little evidence of crowding-out private transfers. We also suggest that recipient household welfare probably increased due to slightly higher expenditures on basic consumption including healthcare, more leisure hours, and improved self-reported health. While measured short-run effects are small, follow-ups will be essential to gauge longer-run behaviors.

\section{Background}

Chile's privately managed pension system has inspired reform in many other countries and is considered by some as a possible prototype for reform in the United States and elsewhere (Arenas de Mesa 2005; Arenas de Mesa et al. 2007; and Barr and Diamond, 2008). Accordingly, in 2008 when the government launched a series of reforms, this aroused substantial international interest (Arenas de Mesa 2010; Kritzer 2008; Packard 2002; and Valdes-Prieto 2009). These changes were driven in part by the fact that many workers did not contribute much to the system; also benefit levels were projected to be low for those who failed to contribute at least 20 years and hence would be ineligible for a guaranteed minimum pension benefit.

The new safety net as implemented includes two big components: a) the Basic Solidarity Pension (PBS, Pension Básica Solidaria) mentioned above, that secures a minimum meanstested benefit for the elderly poor (age 65+) who do not satisfy minimum contribution requirements, and b) a pension top-up (APS, Aporte Previsional Solidario) that increases pension

\footnotetext{
${ }^{1}$ For further discussion of the EPS see Bravo et al. $(2004,2006)$ and Centro de Microdatos (2009).
} 
benefits for those who did contribute to the AFP system. In 2008, the PBS was set at about US\$118/month or about one-third of the minimum monthly wage of US\$333, and nearly $50 \%$ higher than the Minimum Pension Guarantee (Joubert and Todd, 2011). The PBS benefit withdrawal rate is 100 percent for households with income above the governmental poverty threshold (Valdes-Prieto 2009). The PBS was initially targeted at the poorest 40 percent of the population; coverage is set to rise gradually to 60 percent by $2012 .^{2}$ In what follows, we use difference-in-difference analysis to examine the short-run impacts of the PBS targeted towards poor households with at least one member age $65+.^{3}$

Old-Age 'Basic Solidarity Pension': the old-age Basic Solidarity Pension is a monthly benefit paid by the Chilean Government to those who (a) receive no other pension, (b) are age 65+, and (c) are deemed to be in the poorest half of the population according to their poverty score (measured as a "Ficha de Proteccion Social" score of 12,666 points or below). ${ }^{4}$ This benefit has been rolling-out gradually since July 2008 because it represents a large boost in poverty payments. At that time, the benefit was worth US\$105/month and the program aimed to reach

\footnotetext{
${ }^{2}$ Several other reforms were also instituted though they are not the focus here. The self-employed are now to be required to contribute to the individual accounts system with a phase-in; in 2012, their contribution rate will be 10 percent on 40 percent of their pay, and by 2015 , their entire pay will be subject to the 10 percent contribution rate. Additionally, low-wage workers (those earning less than 1.5 times the minimum wage) are to receive a contribution subsidy by employers and the government. Survivor and disability insurance is being extended to working men and women to age 65 (before, women were covered only to age 60), and since women average lower disability rates, they will receive a refund of the excess charges into their individual account pensions. A benefit subsidy is to be paid to mothers age 65 or above who retire from 2009 on and who contributed at least once to an AFP and are in receipt of a solidarity or survivors pension. This benefit is computed as a per-child bond that earns a return from each child's birthdate until the mother reaches age 65. Finally, assets accumulated in workers' individual accounts are now divisible on divorce (which was only recently legalized in Chile), and both widows and widowers are now eligible for survivor pensions (previously only widows received the survivor benefit).

${ }^{3}$ More time must pass to measure the medium and longer-run impacts of the 2008 provisions. An alternative approach to that used in this paper would be to develop and estimate a structural life cycle model that could be used to stimulate counterfactuals under the pension reforms of 2008. A few authors have developed such formulations, but they have not used them to study the 2008 reform (Joubert 2010; Vélez-Grajales 2009).

${ }^{4}$ During the first two years 2008-2010, the FPS score was used to assign the PBS benefit; however, since July 2010 the law establishes the use of a new tool called Puntaje de Focalizacion Previsional (PFP). This new instrument uses the same information captured by the FPS score but in a different way; giving relevance to the information that appears more related to the pension situation. A PFP score of 1,100 or lower was required for the period between July 2010 and June 2011 to be eligible for the PBS benefit.
} 
the poorest 40 percent of the population. By July 2009, the amount had risen to US\$132/month, and coverage was targeted to the poorest 45 percent of the population; the coverage target rose to 50 percent by September 2009, 55 percent by July 2010 and 60 percent as of July 2011, a year before the planned schedule. ${ }^{5}$ Benefits are paid both by the government Social Security administration (IPS, Instituto de Previsión Social, formerly the INP), local municipalities, and the AFPs. To date, the IPS is the main distributor with half a million applications, whereas the AFPs have registered only about 30,000 applications.

\section{Data Overview}

To analyze the near-term impact of the reform we rely on the EPS, which is a panel survey collected by the Microdata Center of the Universidad de Chile with guidance from a University of Pennsylvania research team. ${ }^{6}$ The sample is drawn from a frame of approximately 8.1 million current and former affiliates of the Chilean old-age systems compiled from administrative sources. For this study, we focus on a research file of 10,394 individuals for whom all key dependent variables are available from both the 2006 and 2009 EPSs $^{7}$ to ensure that the multiple outcomes traced over time track changes in responses rather than changes in sample coverage. ${ }^{8}$

\footnotetext{
${ }^{5}$ http://www.safp.cl/573/article-5785.html

${ }^{6}$ Research support was provided by a U.S. National Institutes of Aging (NIA) grant on which three senior coauthors are Co-Investigators to supplement resources provided by the Chilean government.

${ }^{7}$ The total number of respondents was 16,443 in the 2006 EPS and 14,243 in the 2009 EPS. For some dependent variables, sample sizes are smaller. For instance, hours worked are available only for those in the labor force and who report hours worked (5,980 individuals); per capita household expenditures on clothing are available for 10,099 observations; per capita household medical expenditures are available for 9,735; and purchases of private medical insurance are available for 9,737 persons; and for a set of a dozen consumer durables we have between 10,388 and 10,394 responses.

${ }^{8}$ We also note below that results are similar if we consider the largest possible sample for each dependent variable rather than the sample available for all outcomes.
} 
Descriptive statistics for demographic and other factors appear in Table 1. Respondents' average age is 49.7 years $(\mathrm{sd}=14.9)$ and average schooling attainment is 9.8 grades $(\mathrm{sd}=4.3)$, reflective of the fact that Chile has a relatively highly-schooled population for a developing country. The sample is almost half male ( 48.5 percent), and mean household size is 3.9 members $(s d=1.9)$. Almost a third (32 percent) of the households report having a member age $65+$. The mean age of the household head is older, at 53.8 years $(\mathrm{sd}=14.6)$, and schooling attainment slightly lower, at 9.3 grades ( $\mathrm{sd}=4.4)$, compared to all EPS respondents. But where there is a large difference between respondents and household heads is with respect to sex, with about three-quarters (72.9 percent) of household heads being male. Mean annual household income (expressed in constant 2009 terms) is US\$9,650 (sd=US\$14,100), which implies a mean per capita annual household income of US\$2,990 (sd=US\$4,475). ${ }^{9}$ Finally, over half (52.7 percent) of the households have Ficha de Proteccion Social (FPS) scores below the poverty cutoff used to establish eligibility for the reform's means test. ${ }^{10}$ The FPS score was provided from administrative data matched to the EPS respondents, so the FPS values used in the multivariate analysis below are the official scores and not self-reported.

\section{Table 1 here}

To examine the first-round impact of the reform, we examine three sets of outcomes. The first set, shown in Table 2, includes seven variables related to respondent knowledge of the reform and reports of PASIS/PBS ${ }^{11}$ benefit receipt in $2009 .{ }^{12}$ Only about one-quarter (25.9

\footnotetext{
${ }^{9}$ In 2009, the exchange rate between Chilean pesos (CLP) and the US dollar was 569.37 (CIA World Factbook, https://www.cia.gov/library/publications/the-world-factbook/geos/ci.html, accessed 28 August 2010). Household income is missing for one-fifth of the households.

${ }^{10}$ Some 15.1 percent have FPS scores above the eligibility cutoff, about 31.1 percent have no FPS scores and we lack of information for whether or not 1.1 percent of households have a score. A natural interpretation is that respondents lacking an FPS scores were likely ineligible.

${ }^{11}$ Before the reform was implemented in July 2008, some in the targeted population received the PASIS benefit which refers to the former Assistance Pension (Pension Asistencial). After the reform, this group received the higher PBS (paid to individuals 18 years or older who were PASIS beneficiaries prior to the reform who became PBS
} 
percent) of the respondents indicated that they had heard of the pension reform, though more (35.3 percent) said they had heard of the PBS for the elderly and 8.6 percent of the top up (APS) for the elderly. Very few (3.7 percent) said they had received the pre-2008 reform support payment (PASIS) as of June 2008, and about the same fraction (3.6 percent) claimed to be receiving the PBS support as of 2009. Very few, only 6.6 percent, knew that the PBS and APS benefits began in July 2008, and only 12.5 percent knew that the PBS and APS benefits cover the poorest 40-60 percent of the population (with the percentage increasing over time). In summary, very few respondents seemed particularly knowledgeable about the 2008 pension reform though knowledge about the PBS component was more widespread.

\section{Table 2 here}

A second set of outcomes, described in Table 3, refers to transfers received by households in 2006 and 2009, as well as the difference between these two years. These transfers (in constant 2009 US\$) are: (a) PASIS/PBS pension payments, (b) the sum of all public transfers received, and (c) all private transfers received. ${ }^{13}$ In 2006 , the reported average total public transfers and private transfers both totaled around US\$152, though with much greater variation for private transfers received ( $\mathrm{sd}=\mathrm{US} \$ 1,332)$ than for public transfers received ( $\mathrm{sd}=\mathrm{US} \$ 484$ ). PASIS/PBS accounted for about two-thirds (65 percent in 2006 and 66 percent in 2009) of the reported public transfers. Between 2006 and 2009, public transfers rose considerably: the average increased by half to US\$236 for overall reported public transfers and by 60 percent to US $\$ 157$ for PASIS/PBS. At the same time, mean private transfers declined by 12 percent though

beneficiaries automatically as of July 2008). For this reason, when we compare 2006 and 2009 data, we refer to both groups.

${ }_{12}$ An analysis of pension knowledge using earlier EPS surveys is provided in Behrman et al. (2010).

${ }^{13}$ The sum for all public transfers received includes, in addition to the PASIS/PBS pension payment, the family allowance, the Subsidio Unico Familiar (SUF, for recent births, pregnant women, mothers, mental deficiencies, and invalids) and other public subsidies. For PASIS/PBS and for total public transfers both the reported amounts and the corrected amounts (given the actual schedules) were investigated, but none of the conclusions differ importantly between these two alternatives. 
the change was not significant. Thus, public transfers appear to have risen between 2006 and 2009, coincident with the pension reform of July 2008. There is also some suggestion of the possibility of private transfers being crowded-out. Overall, reported public transfers equaled 2.4 percent of mean reported income in 2009, while the PASIS/PBS alone accounted for 1.6 percent and private transfers received accounted for 1.4 percent.

\section{Table 3 here}

A third set of outcomes includes economic and social behaviors such as hours worked, household expenditures, alcohol and cigarette consumption, health insurance, self-reported health status, and ownership of consumer durables. The picture is quite mixed here, since between 2006 and 2009, mean household ownership increased significantly for 9 of the 12 consumer durables considered (the significant decline for landline telephones is offset by the large rise in cellphones). On the other hand, mean household per capita food expenditure declined significantly by 4 percent; cigarette consumption held steady but reported alcohol consumption fell by 15 percent; household per capita clothing expenditures increased significantly by 18 percent; and household per capita educational and medicine expenditures remained the same. Respondents' mean participation in private health insurance decreased significantly by 7 percent and self-reported health status declined significantly by 2 percent. For those employed, mean hours worked remained at about 45 hours per week.

Table 4 here

Multivariate Analysis of 2008 PBS Reform Impacts on Targeted Poor Households with at Least One Member Age 65+ 
Using the 2006 and 2009 EPSs, we next measure the "intent-to-treat" impacts of the PBS component of the 2008 Pension Reform on targeted poor households with at least one member age 65+. Our estimation strategy for transfers received and behavioral outcomes exploits reported changes between 2006 and 2009, along with discontinuities in the applicability of certain provisions of the reform related to the age of household members and the FPS score. We also control for observed characteristics unaffected by the program in triple-difference estimates (because there are two eligibility criteria plus the time difference between 2006 and 2009). For example, to investigate how the PBS transfer influenced an outcome $Y_{t}$ for targeted households, we estimate the following model:

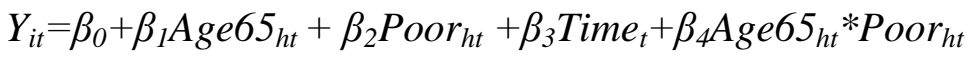

$$
\begin{aligned}
& +\beta_{5}{\text { Age } 65_{h t} * \text { Time }_{t}+\beta_{6} \text { Poor }_{h t} * \text { Time }_{t}+\beta_{7} \text { Age } 5_{h t} * \text { Poor }_{h t} * \text { Time }_{t}+\beta_{8} \text { Controls }_{i t}+v_{i t},}
\end{aligned}
$$

where the subscript $i$ refers to the unit of observation for the dependent variable which may be either the individual respondent or the household depending on the outcome variable; the subscript $h$ refers to the household because some of the right-side variables are household-level variables even if the dependent variable is an individual-level variable (in particular Age65 and Poor); the subscript $t$ refers to the time period; Age65=1 if the household satisfies the age criterion for PBS eligibility (e.g. it has at least one individual age 65+) and zero otherwise; Poor $=1$ if the household has a "Ficha de Proteccion Social" score below the cutoff and zero otherwise; ${ }^{14}$ and Time $=1$ for 2009 (after the introduction of the Reform in 2008) and zero otherwise. We also include a vector of characteristics (controls) unaffected by the program (e.g., for the household head and respondent depending on whether the dependent variable is household-level or respondent-level, sex and a quadratic in age to control for possible life-cycle

\footnotetext{
${ }^{14}$ In our empirical implementation we have a measure of Poor only for 2009 so effectively the time subscript for this variable is suppressed.
} 
patterns) and a stochastic random disturbance term $v$. Our estimate of $\beta_{7}$ measures the "intent-totreat" impact of the PBS component of the 2008 reform on the dependent variable of interest in 2009 for targeted poor households with at least one household member age $65+$ who meet the age and poverty requirements to receive the PBS, holding constant observed household variables (and through the triple-difference procedure, unobserved fixed household characteristics).

Only the 2009 wave contains relevant information for the knowledge of the 2009 pension reform and reported receipt of PASIS/PBS transfers. Accordingly, we generate double-difference estimates using only the 2009 data; that is, in the equation above, all terms involving Time $_{t}$ are constrained to zero (i.e., $\beta_{3}=\beta_{5}=\beta_{6}=\beta_{7}=0$ ) and the estimate of $\beta_{4}$ reflects the impact of the PBS reform on key outcomes. Again we control for observed household/respondent variables and, through the double-difference procedure, unobserved fixed household/respondent characteristics.

Table 5 summarizes findings for the pension reform knowledge and reports of PASIS/PBS transfers. Five of the dependent variables are dichotomous $(0=$ no; $1=$ yes $)$, so probit estimates are presented for these variables. Two others are trichotomous $(0=$ incorrect; 1 $=$ do not know; $2=$ correct), so we use multinomial probits for these (Table 5 presents marginal effects). Of key interest is the fact that the linear term for having someone age $65+$ in the household is statistically significant in only one of the seven outcomes: respondents are significantly more likely to say they receive the PBS at the time of the 2009 survey if there is a household member age $65+$. The linear term for being poor is statistically significant for five of the seven dependent variables; it is negative for having heard of the pension reform, having heard of the PBS for the elderly, having heard of the APS for the elderly, and not knowing ${ }^{15}$ when the pension reform began. It is positive for having received the PASIS and having received the PBS. Thus, ceteris paribus, the poor are less-well informed than the non-poor but more likely

\footnotetext{
${ }^{15}$ That is, responding they "do not know," as opposed to responding wrongly or correctly.
} 
to report receiving the PASIS/PBS targeted transfers. Of most interest are the interaction terms between having a person age 65 or older in the household and being poor. Among the seven dependent variables examined, only the one for having heard of the PBS for the elderly has a positive significant coefficient estimate.

\section{Table 5 here}

Next we turn to household transfers received, summarized in Table 6. Now the linear terms and double interactions for having someone age $65+$ in the household, the year 2009, and the household being poor, are all positive and significant for all of the public transfers, as well as for the PASIS/PBS (with a single exception of the year 2009 variable for the latter). By contrast, none of these is significant for receiving private transfers. The coefficient estimate of primary interest, of course, is the triple interaction because this estimate gives the estimated average impact of the 2008 reform on 2009 outcomes for poor households having someone age 65 or older. These estimates are significantly positive and substantial for PASIS/PBS (US\$105 per year) and for total public transfers received (US\$107 per year). The estimate is not statistically significant for private transfers received, so there is little evidence of crowding-out of private transfers by larger public transfers.

\section{Table 6 here}

Next we turn to estimated triple-difference impacts on household behaviors. Table 7 reports estimates on four types of per capita household expenditures (food, clothing, education, medicine) and five respondent behaviors (cigarette consumption, alcohol consumption, private health insurance purchases, self-rated health status and weekly hours worked), while Table 8 reports estimates for a dozen purchases of consumer durables/services (TV, refrigerator, washing machine, oven, hot water heater, landline phone, cell phone, DVD, microwave, computer, 
internet connection, and cable TV). For these estimates, the linear coefficient for having a household member age $65+$ is significantly negative for household per capita clothing expenditures, household per capita educational expenditures, and household ownership of cell phones, DVDs, computers, and internet connections. In contrast, the estimates are significantly positive for the number of TVs and landline phones, as well as for the highest categories in respondent self-rated health. The linear associations with the year 2009 are significantly negative with household per capita food expenditures, respondent alcohol consumption, and household ownership of landline phones and ovens, and significantly positive for per capita clothing expenditures and ownership of washing machines, hot water heaters, cell phones, DVDs, microwaves, computers, internet connections and TV cable. The linear associations with being poor are significantly negative for per capita food, clothing and educational expenditures, cigarettes and alcohol consumption, private health insurance, the highest categories in selfrelated health, hours worked per week, and household ownership of eleven consumer durables (the exception is ownership of ovens). Accordingly these results are fairly plausible a priori. There also are a number of significant double interactions ( 27 percent of the 63 possibilities) summarized in Table 9, about 65 percent of which ameliorate the negative associations of being poor for households with a member age $65+$ in 2009.

\section{Tables 7, 8, and 9 here}

For the purpose of evaluating the short-run impact of the reform, the key coefficient estimates are those of the triple-difference terms which are positive for three of the four household expenditure categories: cigarette consumption; private insurance, and the three highest categories in self-reported health status; as well as five of the consumer durable purchase amounts. They are negative in other cases with perhaps the most interesting being the fairly large 
reduction of 1.6 work hours per week. Thus, there is some suggestion that the PBS impact on targeted households may have been to boost expenditures on basic household consumption including on health, enhance respondent leisure by reducing hours worked, and improve respondent self-reported health, with mixed effects on respondent cigarette versus alcohol intake and on the composition of consumer durables. This pattern could be interpreted to be somewhat welfare-enhancing for the targeted poor households having an older member in 2009.

Nevertheless, two important qualifications must be noted. First, with the exception of the increase in leisure through hours worked reductions, estimated effects are not quantitatively large. For instance, our estimated increase in annual expenditures on food, clothing, and medicine, represent only an annual US\$13, US\$1 and US\$16, respectively. Second these estimates are not significantly different from zero at the standard 5 percent level; the two most significant coefficient estimates are for (a) respondent self-reported health status (significantly nonzero at the 10 percent level) and (b) hours worked per week (significantly nonzero at the 15 percent level).

\section{Conclusions}

Our study is the first systematic effort to directly evaluate the short-run impacts of Chile's pension reform of 2008. We focus on a key component, the Basic Solidarity Pension or PBS for the elderly, directed towards poor households with at least one person age $65+$. We find that, in 2009, the poor were less-well informed about the reform than the non-poor, but they were nevertheless more likely to report receiving the PASIS/PBS transfers targeted on the poor. One significant program impact is that respondents living in a poor household with someone age $65+$ are more likely than others to have heard of the PBS for the elderly. We find a significant 
positive impact of the reform among the targeted poor having an older household member where respondents indicate receiving an annual US\$105from PASIS/PBS transfers. There is little evidence of public benefits crowding-out private transfers. There is also some suggestion that the targeted transfers led households to boost expenditures on health, increase leisure, and improve self-reported health, with mixed effects on cigarette versus alcohol intake and on the composition of consumer durables.

This pattern might seem to be somewhat welfare-enhancing for poor households with at least one older member in 2009. Nevertheless, such a conclusion must be heavily qualified because, with the exception of the reduction in work hours of 1.6 hours per week, the estimated effects are small and none of the underlying coefficient estimates are significantly nonzero at the standard 5 percent level. These insignificant and generally small effects raise questions about what happened to the reported increased income from the increased PASIS/PBS as well as questions about how these impact patterns will evolve. Part of the answer, despite the impression of the estimates, may be in crowding-out private transfers received and inducing reductions in work. As has been noted elsewhere (e.g., Behrman and King 2008; King and Behrman 2009), there also are a number of reasons to expect adjustments over time in implementation of reforms and in private responses to those reforms. ${ }^{16}$ Therefore, it will be very important, in the future, to monitor and evaluate the time pattern of a broad array of responses to the components of the Reform introduced in 2008, as well as to the components of the Reform being phased in over time.

\footnotetext{
${ }^{16}$ A related observation in term often used in the 'impact evaluation' literature is that we are estimating "intent to treat" effects. But if there are implementation delays, the "intent to treat" group may be much larger than the "treatment of the treated" group, initially, even if eventually they become approximately the same over time.
} 


\section{References}

Arenas de Mesa, Alberto. 2005. "Fiscal and Institutional Considerations of Pension Reform: Lessons Learned from Chile." In Carolyn A. Crabbe, ed. A Quarter Century of Pension Reform in Latin America and the Caribbean: Lessons Learned and the Next Steps, Washington, DC: Inter-American Development Bank, 83-126.

Arenas de Mesa, Alberto. 2010. Historia de la Reforma Previsional Chilena: Una Experiencia Exitosa de Política Pública en Democracia. Santiago, Chile: Oficina Internacional del Trabajo.

Arenas de Mesa, Alberto, Jere R. Behrman, David Bravo, Olivia S. Mitchell and Petra E. Todd (with the assistance of Andres Otero, Jeremy Skog, Javiera Vasquez and Viviana VelezGrajales).1997."The Chilean Pension Reform Turns 25: Lessons from the Social Protection Survey." In Stephen J. Kay and Tapen Sinha, eds. Lessons from Pension Reform in the Americas Oxford University Press.

Barr, Nick and Peter Diamond. 2008. Reforming Pensions: Principles and Policy Choices. Oxford, Oxford University Press.

Behrman, Jere R. and Elizabeth M. King. 2008. "Program Impact and Variation in Duration of Exposure." In Samia Amin, Jishnu Das, and Markus Goldstein, eds, Are You Being Served: New Tools for Measuring Service Delivery, Washington, DC: World Bank, 147172.

Behrman, Jere R., Olivia S. Mitchell, Cindy Soo, and David Bravo. 2010. "Financial Literacy and Pension Wealth Accumulation." NBER Working Paper 16452, October.

Berstein, Solange, Guillermo Larrain, and Francisco Pino. 2006. "Chilean Pension Reform: Coverage Facts and Policy Alternatives." Journal of the Latin American and Caribbean Economic Association 6(2): 227-279.

Bravo, David, Jere Behrman, Olivia S. Mitchell, and Petra Todd. 2004. Análisis y Principales Resultados: Primera Encuesta de Protección Social (Historia Laboral y Seguridad Social, 2002).Santiago, Chile: Centro de Microdatos, Universidad de Chile

Bravo, David, Jere R. Behrman, Olivia Mitchell and Petra E. Todd. 2006, Encuesta de Protección Social 2004: Presentación General y Resultados Principales. Santiago, Chile: Centro de Microdatos, Universidad de Chile.

Centro de Microdatos. 2009. EPS 2008 Manual para el Trabajo de Campo. Universidad de Chile. Santiago, Chile: Centro de Microdatos, Universidad de Chile.

Gill, Indermit S., Truman Packard, and Juan Yermo. 2005. Keeping the Promise: Of Old Age Income Security In Latin America. Stanford, CA: Stanford University Press.

Díaz, Carlos, Osvaldo Larrañaga, Mónica Titze, Andras Uthoff, David Bravo, Alejandra Candia. 2009. Informe del Consejo Consultivo Previsional. Gobierno de Chile: Subsecretaria de Prevision Social.

Joubert, Clement. 2010. "A Structural Estimation of the Effect of Mandatory Contributions on Pension Coverage," Philadelphia, PA: University of Pennsylvania, Ph.D. dissertation.

Joubert, Clement and Petra Todd. 2011. "The Impact of Chile's 2008 Pension Reform on Labor Force Participation, Pension Savings, and Gender Equity." Univ. of Pennsylvania, Working Paper. 
King, Elizabeth M. and Jere R. Behrman. 2009."Timing and Duration of Exposure in Evaluations of Social Programs," World Bank Research Observer (February) 24: 55 82.

Kritzer, Barbara E. 2008. “Chile's Next Generation Pension Reform.” Social Security Bulletin. 68 (2): 69-84.

Kritzer, Barbara E., Stephen J. Kay, and Tapen Sinha. 2011. "Next Generation of Individual Account Pension Reforms in Latin America." Social Security Bulletin 71(1): 35-76.

Mesa-Lago, Carmelo. 2008. Reassembling Social Security. Oxford: Oxford University Press.

Packard, Truman. 2002. "Are There Positive Incentives from Privatizing Social Security? A Panel Analysis of Pension Reform in Latin America." Journal of Pension Economics and Finance 1(2).

Valdes-Prieto, Salvador. 2009. "The 2008 Chilean Reform to First-Pillar Pensions." CESIFO Working Paper 2520, January.

Vélez-Grajales, Viviana. 2009. "Reforms to an Individual Account Pension System and their Effects on Work and Contribution Decisions: The Case of Chile." Philadelphia, PA: University of Pennsylvania, Ph.D. dissertation. 
Table 1. Descriptive Statistics for Controls and Selected Other Variables

\begin{tabular}{|c|c|c|}
\hline & Mean & Sd. Dev. \\
\hline \multicolumn{3}{|l|}{ Respondent Characteristics } \\
\hline Schooling attainment (grade) & 9.8 & 4.3 \\
\hline Age (years) & 49.7 & 14.9 \\
\hline Male $(\%)$ & 48.5 & \\
\hline \multicolumn{3}{|l|}{ Household Characteristics } \\
\hline Number of members & 3.9 & 1.9 \\
\hline One or more member $>=65$ years $(\%)$ & 32.0 & \\
\hline HH head schooling attainment (grades) & 9.3 & 4.4 \\
\hline HH head age (years) & 53.8 & 14.6 \\
\hline HH head male (\%) & 72.9 & \\
\hline Income (2009 USD) & 9,657 & 14,087 \\
\hline Income per capita (2009 USD) & 2,994 & 4,475 \\
\hline Income missing $(\%)$ & 21.2 & \\
\hline Poor based on FPS score (\%) & 52.7 & \\
\hline
\end{tabular}

Notes: $\mathrm{N}=10,394$ except for household income and household income per capita for which cases N=8,195. FPS stands for Ficha de Proteccion Social . 
Table 2. Descriptive Statistics for 2009 Knowledge of the Pension Reform and Reporting Receiving PASIS/PBS Transfers

\begin{tabular}{|c|c|c|c|c|c|}
\hline & $\begin{array}{l}\text { Have you heard } \\
\text { about the Pension } \\
\text { Reform? }\end{array}$ & $\begin{array}{l}\text { Do you know or have } \\
\text { you heard about the } \\
\text { Basic Pension } \\
\text { System (PBS) for } \\
\text { the Elderly? }\end{array}$ & \begin{tabular}{|c|} 
Do you know or have \\
you heard of the \\
Pension \\
Contribution \\
System (APS) for \\
the Elderly?
\end{tabular} & $\begin{array}{l}\text { By June 2008, } \\
\text { Were you a } \\
\text { beneficiary of the } \\
\text { Support Pension } \\
\text { PASIS? }\end{array}$ & $\begin{array}{l}\text { Currently, are you } \\
\text { receiving the Basic } \\
\text { Pension System } \\
\text { (PBS)? }\end{array}$ \\
\hline No $(\%)$ & 74.1 & 64.75 & 91.42 & 96.31 & 96.44 \\
\hline Yes $(\%)$ & 25.9 & 35.25 & 8.58 & 3.69 & 3.56 \\
\hline \multirow[t]{2}{*}{ Total } & 100 & 100 & 100 & 100 & 100 \\
\hline & \multicolumn{2}{|c|}{$\begin{array}{l}\text { Since when do you think the people will } \\
\text { receive the benefits of the Basic Pension } \\
\text { System (PBS) and the Pension } \\
\text { Contribution System (APS)? }\end{array}$} & \multicolumn{2}{|c|}{$\begin{array}{l}\text { What percentage of the population in the } \\
\text { country do you believe will receive the } \\
\text { benefits of the Basic Pension System } \\
\text { (PBS) and Pension Contribution System } \\
\text { (APS)? }\end{array}$} & \\
\hline Incorrect (\%) & \multicolumn{2}{|c|}{20.69} & \multicolumn{2}{|c|}{21.4} & \\
\hline DNK/ NR (\%) & \multicolumn{2}{|c|}{72.72} & \multicolumn{2}{|c|}{66.12} & \\
\hline Correct (\%) & \multicolumn{2}{|c|}{6.6} & \multicolumn{2}{|c|}{12.49} & \\
\hline Total & \multicolumn{2}{|c|}{100} & \multicolumn{2}{|c|}{100} & \\
\hline
\end{tabular}


Table 3. Descriptive Statistics for Selected Annual Transfers Received by Households (in 2009 US\$)

\begin{tabular}{|c|c|c|c|c|c|c|c|c|}
\hline & Mean & Sd. Dev. & $\begin{array}{l}\text { \% HHs that } \\
\text { receive the }\end{array}$ & Mean & Sd. Dev. & $\begin{array}{l}\text { \% HHs that } \\
\text { receive the }\end{array}$ & \multicolumn{2}{|c|}{ Difference in means } \\
\hline & \multicolumn{3}{|c|}{2006} & \multicolumn{3}{|c|}{2009} & $2009-2006$ & p-value \\
\hline Total public transfers received & 151.8 & 483.6 & 28.8 & 235.8 & 603.2 & 35.5 & 84.1 & 0.000 \\
\hline PASIS/PBS transfer & 98.1 & 457.4 & 7.0 & 156.6 & 571.1 & 9.7 & 58.5 & 0.000 \\
\hline Total private transfers received & 151.7 & $1,332.2$ & 7.3 & 133.6 & $1,127.7$ & 6.8 & -18.0 & 0.292 \\
\hline
\end{tabular}


Table 4. Descriptive Statistics for Household and Respondent Behavioral Outcomes

\begin{tabular}{|c|c|c|c|c|c|c|c|}
\hline & & \multicolumn{2}{|c|}{2006} & \multicolumn{2}{|c|}{2009} & \multicolumn{2}{|c|}{ Difference in Means } \\
\hline & & Mean & Sd. Dev. & Mean & Sd. Dev. & $2009-2006$ & p-value \\
\hline \multicolumn{8}{|c|}{ Annual household expenditures per capita (constant 2009 USD) } \\
\hline & Food & 741 & 867 & 711 & 550 & -29 & 0.004 \\
\hline & Education & 341 & 916 & 328 & 875 & -14 & 0.266 \\
\hline & Clothing & 85 & 267 & 100 & 179 & 15 & 0.000 \\
\hline & Medicine & 87 & 932 & 89 & 916 & 2 & 0.863 \\
\hline \multicolumn{8}{|c|}{ Household consumer durables and services (number) } \\
\hline & TV & 1.83 & 1.05 & 1.88 & 1.02 & 0.05 & 0.000 \\
\hline & Refrigerator & 0.96 & 0.36 & 0.97 & 0.32 & 0.00 & 0.509 \\
\hline & Washing machine & 0.74 & 0.47 & 0.79 & 0.43 & 0.06 & 0.000 \\
\hline & Oven & 1.01 & 0.25 & 1.00 & 0.22 & -0.01 & 0.000 \\
\hline & Hot water heater & 0.67 & 0.51 & 0.69 & 0.51 & 0.02 & 0.013 \\
\hline & Landline phone & 0.55 & 0.58 & 0.53 & 0.57 & -0.03 & 0.001 \\
\hline & Cell phone & 1.46 & 1.36 & 1.68 & 1.32 & 0.22 & 0.000 \\
\hline & DVD & 0.71 & 0.69 & 0.74 & 0.68 & 0.03 & 0.001 \\
\hline & Microwave & 0.47 & 0.51 & 0.53 & 0.52 & 0.06 & 0.000 \\
\hline & Computer & 0.38 & 0.58 & 0.50 & 0.66 & 0.12 & 0.000 \\
\hline & Internet connection & 0.17 & 0.39 & 0.28 & 0.48 & 0.11 & 0.000 \\
\hline & Cable TV & 0.25 & 0.46 & 0.38 & 0.51 & 0.13 & 0.000 \\
\hline \multicolumn{8}{|l|}{ Respondent } \\
\hline & Number of cigarettes smoked per month & 47.0 & 116.6 & 47.4 & 120.3 & 0.5 & 0.778 \\
\hline & Number of glasses of alcohol consumed per week & 2.3 & 5.3 & 2.0 & 4.7 & -0.4 & 0.000 \\
\hline & Health insurance is private $(\%)$ & 13 & & 12 & & -1 & 0.048 \\
\hline & Self-reported health status ( $1=$ very bad; $6=$ excellent $)$ & 3.7 & 1.0 & 3.7 & 0.9 & -0.1 & 0.000 \\
\hline & Hours worked (weekly) & 45.1 & 13.2 & 44.8 & 13.1 & -0.4 & 0.141 \\
\hline
\end{tabular}

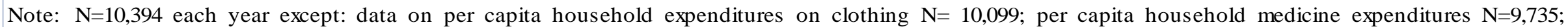
purchasing private medical insurance $\mathrm{N}=9,737$; hours worked $\mathrm{N}=5,980$; and for the 12 consumer durables and services $\mathrm{N}$ ranges from 10,388 to 10,394 . 


\begin{tabular}{|c|c|c|c|c|c|c|c|c|c|c|c|}
\hline & $\begin{array}{l}\text { Have you } \\
\text { heard about } \\
\text { the pension } \\
\text { reform? }\end{array}$ & $\begin{array}{l}\text { Do you know } \\
\text { or have you } \\
\text { heard about } \\
\text { the Basic } \\
\text { Pension }\end{array}$ & \begin{tabular}{|l|} 
Do you know \\
or have you \\
heard of the \\
Pension \\
Contribution
\end{tabular} & \begin{tabular}{|c|} 
By June \\
2008, Were \\
you a \\
beneficiary of \\
the Support \\
\end{tabular} & $\begin{array}{l}\text { Currently, } \\
\text { are you } \\
\text { receiving the } \\
\text { Basic } \\
\text { Pension }\end{array}$ & \multicolumn{3}{|c|}{$\begin{array}{c}\text { Since when do you think the people will } \\
\text { receive the benefits of the Basic Pension } \\
\text { System and the Pension Contribution } \\
\text { System? }\end{array}$} & \multicolumn{3}{|c|}{$\begin{array}{l}\text { What percentage of the population in the } \\
\text { country do you believe will apply the } \\
\text { benefits of the Basic Pension System and } \\
\text { Pension Contribution System? }\end{array}$} \\
\hline & \multicolumn{5}{|c|}{ probit } & \multicolumn{6}{|c|}{ multinomial probit } \\
\hline & \multicolumn{5}{|c|}{$0=$ no; 1 = yes } & $\begin{array}{l}\text { outcome = } \\
\text { incorrect }\end{array}$ & $\begin{array}{l}\text { outcome = } \\
\text { DNK/ NR }\end{array}$ & $\begin{array}{c}\text { outcome = } \\
\text { correct }\end{array}$ & $\begin{array}{l}\text { outcome = } \\
\text { incorrect }\end{array}$ & $\begin{array}{l}\text { outcome = } \\
\text { DNK } / \text { NR }\end{array}$ & $\begin{array}{c}\text { outcome = } \\
\text { correct }\end{array}$ \\
\hline \multicolumn{12}{|l|}{ Linear terms } \\
\hline HH member $>=$ age 65 & 0.023 & 0.016 & -0.002 & 0.011 & $0.029 *$ & 0.011 & -0.038 & 0.027 & 0.029 & -0.030 & 0.001 \\
\hline Poor & $-0.081 * * *$ & $-0.063 * * *$ & $-0.023^{*}$ & $0.021 * * *$ & $0.026 * *$ & $-0.029 *$ & 0.030 & -0.001 & -0.020 & 0.021 & -0.002 \\
\hline \multicolumn{12}{|l|}{ Double interactions } \\
\hline Poor $*$ HH member $>=$ age 65 & -0.012 & $.0624381 *$ & 0.007 & 0.008 & -0.004 & 0.004 & 0.007 & -0.011 & -0.030 & 0.025 & 0.004 \\
\hline \multicolumn{2}{|l|}{$* \mathrm{p}<0.05, * * \mathrm{p}<0.01, * * * \mathrm{p}<0.001$} & & & & & & & & & & \\
\hline
\end{tabular}


Table 6. Annual Transfers Received by Households in 2009 US\$

\begin{tabular}{|c|c|c|c|}
\hline & $\begin{array}{l}\text { All Public } \\
\text { Transfers } \\
\end{array}$ & PASIS/ PBS & $\begin{array}{c}\text { All Private } \\
\text { Transfers }\end{array}$ \\
\hline \multicolumn{4}{|l|}{ Linear terms } \\
\hline HH member $>=$ age 65 & $52.03 * *$ & $42.81^{*}$ & 23.44 \\
\hline Year 2009 & $17.93 * * *$ & 2.87 & -9.96 \\
\hline Poor & $84.56 * * *$ & $33.77 * * *$ & 17.57 \\
\hline \multicolumn{4}{|l|}{ Double interactions } \\
\hline HH member $>=$ age $65 *$ Year 2009 & $60.99 * *$ & $67.80 * *$ & 3.58 \\
\hline Poor $*$ HH member $>=$ age 65 & $113.82 * * *$ & $132.29 * * *$ & -45.39 \\
\hline Poor * Year 2009 & $45.78 * *$ & $20.79 * *$ & -13.41 \\
\hline \multicolumn{4}{|l|}{ Triple interactions } \\
\hline Year $2009 *$ Poor $*$ HH member $>=$ age 65 & $106.89 * *$ & $104.85 * *$ & -28.98 \\
\hline
\end{tabular}

Notes: $\mathrm{N}=20,788(10,394$ respondents each year). Reference category is non-poor (poverty score above the cutoff) + household did not apply for poverty score + do not know if household applied for poverty score. HH head's age, age squared and gender included as controls. 


\begin{tabular}{|c|c|c|c|c|c|c|c|c|c|c|c|c|c|c|}
\hline & \multicolumn{4}{|c|}{$\begin{array}{c}\text { Annual Household Per Capita Expenditures } \\
\text { (2009 USD) }\end{array}$} & \multicolumn{10}{|c|}{ Respondent Behaviors } \\
\hline & \multirow{2}{*}{$\begin{array}{c}\text { Food } \\
(\text { OLS })\end{array}$} & \multirow{2}{*}{$\begin{array}{c}\text { Education } \\
\text { (OLS) }\end{array}$} & \multirow{2}{*}{$\begin{array}{c}\text { Clothing } \\
\text { (OLS) }\end{array}$} & \multirow{2}{*}{$\begin{array}{l}\text { Medicine } \\
\text { (OLS) }\end{array}$} & \multirow{2}{*}{$\begin{array}{c}\text { Number } \\
\text { cigarettes } \\
\text { per month } \\
\text { (OLS) }\end{array}$} & \multirow{2}{*}{$\begin{array}{c}\text { Number } \\
\text { glasses of } \\
\text { alcohol per } \\
\text { week } \\
\text { (OLS) }\end{array}$} & \multirow{2}{*}{\begin{tabular}{|c} 
Health \\
insurance, \\
probit \\
marginal \\
effects
\end{tabular}} & \multicolumn{6}{|c|}{ Self-reported health status, ordered probit marginal effects } & \multirow{2}{*}{$\begin{array}{c}\text { Hours } \\
\text { worked } \\
\text { weekly } \\
(\text { OLS) }\end{array}$} \\
\hline & & & & & & & & $\begin{array}{c}\text { outcome = } \\
\text { very bad }\end{array}$ & $\underset{\text { bad }}{\text { outcome }}=$ & $\begin{array}{l}\text { outcome }= \\
\text { reasonable }\end{array}$ & $\begin{array}{l}\text { outcome }= \\
\text { good }\end{array}$ & $\begin{array}{c}\text { outcome = } \\
\text { very good }\end{array}$ & $\begin{array}{l}\text { outcome }= \\
\text { excellent }\end{array}$ & \\
\hline \multicolumn{15}{|l|}{ Linear terms } \\
\hline HH member $>=$ age 65 & -10.66 & $-221.38 * * *$ & $-23.03 * *$ & 5.66 & -3.53 & 0.24 & -0.01 & $-0.001 *$ & $-0.008^{*}$ & $-0.02 *$ & $0.014^{*}$ & $0.009 *$ & $0.006^{*}$ & -0.91 \\
\hline Year 2009 & $-41.20 *$ & -27.81 & $30.47 * * *$ & 16.25 & 1.97 & $-0.39 * * *$ & -0.001 & 0.000 & 0.002 & 0.004 & -0.003 & -0.002 & -0.001 & -0.27 \\
\hline Poor & $-310.68 * * *$ & $-297.26 * * *$ & $-62.11 * * *$ & -52.68 & $-8.13 * *$ & $-0.42 * * *$ & $-0.18 * * *$ & $0.006 * * *$ & $0.04 * * *$ & $0.088 * * *$ & $-0.065 * * *$ & $-0.041 * * *$ & $-0.029 * * *$ & $-1.1 * *$ \\
\hline \multicolumn{15}{|l|}{ Double interactions } \\
\hline HH member >= age $65 *$ Year 2009 & -18.27 & 24.18 & -12.56 & -17.48 & -0.22 & 0.05 & 0.001 & 0.001 & 0.006 & 0.013 & -0.010 & -0.006 & -0.004 & 0.84 \\
\hline Poor $*$ HH member $>=$ age 65 & 6.56 & $171.39 * * *$ & $24.66 * *$ & -3.90 & 0.49 & -0.11 & $0.035^{*}$ & 0.001 & 0.004 & 0.008 & -0.006 & -0.004 & -0.003 & 0.51 \\
\hline Poor * Year 2009 & 20.99 & 21.82 & $-18.24 *$ & -23.84 & -1.53 & 0.25 & $-0.012 *$ & 0.000 & 0.000 & 0.001 & -0.001 & 0.000 & 0.000 & -0.23 \\
\hline \multicolumn{15}{|l|}{ Triple interactions } \\
\hline Year $2009 *$ Poor $*$ HH member $>=$ age 65 & 13.18 & -4.50 & 0.70 & 15.85 & 4.38 & -0.01 & 0.005 & -0.001 & -0.01 & -0.02 & 0.01 & 0.01 & 0.01 & -1.62 \\
\hline
\end{tabular}

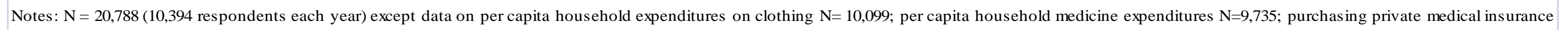

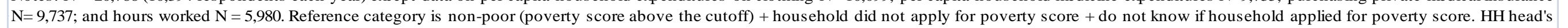
age, age squared and gender included as controls in expenditures regressions and respondent's age, age squared and gender included in behavior regressions. 


\section{Table 8. OLS Estimates for Household Durable}

\begin{tabular}{|c|c|c|c|c|c|c|c|c|c|c|c|c|}
\hline $\begin{array}{l}\text { How many of the following devices do you } \\
\text { have in your household? }\end{array}$ & TV & Refrigerator & $\begin{array}{l}\text { Washing } \\
\text { Machine }\end{array}$ & Oven & $\begin{array}{c}\text { Hot Water } \\
\text { Heater }\end{array}$ & $\begin{array}{l}\text { Landline } \\
\text { Phone }\end{array}$ & Cell Phone & DVD & Microwave & Computer & $\begin{array}{c}\text { Internet } \\
\text { Connection }\end{array}$ & Cable TV \\
\hline \multicolumn{13}{|l|}{ Linear terms } \\
\hline $\mathrm{HH}$ member $>=$ age 65 & $0.081^{*}$ & 0.02 & 0.01 & 0.01 & 0.03 & $0.049 *$ & $-0.307 * * *$ & $-0.068 * *$ & -0.01 & $-0.074 * * *$ & $-0.036^{*}$ & 0.03 \\
\hline Year 2009 & 0.03 & -0.01 & $0.036^{* * *}$ & $-0.014 * *$ & $0.019 * *$ & $-0.066 * * *$ & $0.130 * * *$ & $0.043^{* *}$ & $0.064 * * *$ & $0.152 * * *$ & $0.159 * * *$ & $0.148 * * *$ \\
\hline Poor & $-0.461 * * *$ & $-0.089 * * *$ & $-0.177 * * *$ & -0.01 & $-0.276^{* * *}$ & $-0.294 * * *$ & $-0.463 * * *$ & $-0.2612 * * *$ & $-0.242 * * *$ & $-0.351 * * *$ & $-0.221 * * *$ & $-0.216 * * *$ \\
\hline \multicolumn{13}{|l|}{ Double interactions } \\
\hline HH member $>=$ age $65 *$ Year 2009 & 0.00 & -0.01 & 0.01 & 0.00 & -0.01 & 0.03 & $0.114^{*}$ & 0.01 & -0.02 & $-0.064 * *$ & $-0.036^{*}$ & $-0.042 *$ \\
\hline Poor * HH member $>=$ age 65 & -0.06 & 0.00 & -0.01 & -0.01 & 0.03 & 0.00 & $0.116^{*}$ & 0.01 & 0.02 & $0.103 * * *$ & $0.071 * * *$ & 0.00 \\
\hline Poor * Year 2009 & 0.03 & $0.024 * *$ & $0.034 * *$ & 0.00 & 0.00 & $0.049 * * *$ & $0.156^{* * *}$ & -0.01 & 0.02 & -0.01 & $-0.056^{* * *}$ & -0.01 \\
\hline \multicolumn{13}{|l|}{ Triple interactions } \\
\hline Year $2009 *$ Poor $*$ HH member $>=$ age 65 & 0.06 & 0.01 & 0.00 & 0.01 & -0.01 & -0.01 & -0.10 & 0.01 & -0.02 & -0.01 & -0.01 & 0.00 \\
\hline
\end{tabular}

$* \mathrm{p}<0.05, * * \mathrm{p}<0.01, * * * \mathrm{p}<0.001$

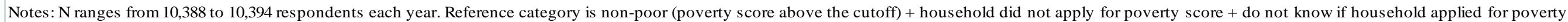
score. HH head's age, age squared and gender included as controls. 
Table 9. Signs of Significant Associations of Interactions for Behavioral Outcomes

\begin{tabular}{|c|c|c|c|c|c|}
\hline \multicolumn{2}{|c|}{ Interaction between } & \multicolumn{2}{|c|}{ Interaction between } & \multicolumn{2}{|c|}{ Interaction between } \\
\hline HH member $>=$ age 65 & Year 2009 & Poor & HH member $>=$ age 65 & Poor & Year 2009 \\
\hline positive & negative & positive & negative & positive & negative \\
\hline \multirow[t]{6}{*}{ cell phone } & computer & clothing & & refrigerator & clothing \\
\hline & internet & education & & washer & internet \\
\hline & cable TV & cell phone & & land phone & private health insurance \\
\hline & & computer & & cell phone & \\
\hline & & internet & & & \\
\hline & & private health in & & & \\
\hline
\end{tabular}

Note: Based on Tables 7 and 8. Except for private health insurance, these all are household level outcomes. 